\title{
Abū Bakr al-Rāzī on Animals
}

\author{
Peter Adamson \\ Fakultät für Philosophie, Ludwig-Maximilians-Universität München, \\ Geschwister-Scholl-Platz 1, 80539 München, Germany, \\ peter.adamson@1rz.uni-muenchen.de
}

\begin{abstract}
Abū Bakr al-Rāzī (d. 925), a doctor known not only for his medical expertise but also for his notorious philosophical ideas, has not yet been given due credit for his ideas on the ethical treatment of animals. This paper explores the philosophical and theological background of his remarks on animal welfare, arguing that al-Rāzī did not (as has been claimed) see animals as possessing rational, intellectual souls like those of humans. It is also argued that al-Rāzi probably did not, as is usually believed, endorse human-animal transmigration. His ethical stance does not in any case depend on shared characteristics of humans and animals, but rather on the need to imitate God's providence and mercy.
\end{abstract}

Ancient philosophers had a good deal to say about animals and how humans should treat them. ${ }^{1}$ Views ran the gamut from the Stoics, who saw such a wide gap between human and animal that they found it problematic to explain how animals could make even the most basic inferences, to Porphyry, who wrote a lengthy treatise arguing that no true philosopher would be willing to sacrifice and eat animals. Such texts have come under increasing scrutiny in recent years. ${ }^{2}$ The situation with respect to the Islamic tradition is rather different. One would not think, surveying the literature, that this tradition has much to offer in the way of philosophical reflection on animals. There are some fairly well-known exceptions, for instance Avicenna's discussion of animals in his theory of the 'internal senses' ${ }^{3}$ and the debate between animals and man in the Epistles of the Brethren of Purity. ${ }^{4}$ Yet there is at least one author whose contribution to the subject of animal welfare has been largely overlooked: the celebrated doctor and notorious philosopher Abū Bakr Muhammad ibn Zakariyyā' al-Rāzī (d. 925 AD).

Few philosophical writings of al-Rāzī are extant. Thus, it is remarkable that in two of the preserved writings, he deals at some length with the question of animal welfare. These texts are entitled The Philosophical Life (al-

1 Note that in this paper I will use the word 'animal' to refer to non-human animals only.

2 See for instance Sorabji 1993, Osborne 2007.

3 See e.g. Black 1993.

${ }^{4}$ See now Goodman and McGregor 2010.

Archiv f. Gesch. d. Philosophie Vol. 94, pp. 249-273

(C) Walter de Gruyter 2012

ISSN 0003-9101

DOI 10.1515/agph-2012-0011 
Sira al-falsafiyya) and The Spiritual Medicine (al-Tibb al-rūhānī), and are of very different character. ${ }^{5}$ The Philosophical Life is al-Rāzì's attempt to defend himself against unnamed detractors, who have among other things accused him of failing to live up to the ascetic example of his 'imäm' Socrates. In this short treatise, he refers back to his more extended discussion in The Spiritual Medicine, a longer work modelled on the ethical writings of Galen. There, al-Rāzì follows Galen in approaching ethical development as a quasi-medical procedure, and dispenses ethical advice the way a doctor might prescribe a diet. On both occasions, he argues with considerable force that it is wrong to cause harm or pain to animals, and that one may do so only under certain carefully proscribed circumstances. Since these passages have received very little attention, my aim here is to set out his argument and determine exactly what obligations he thinks humans bear towards animals.

In pursuit of this aim, I will first sketch some ideas about the ethical status of animals found in al-Rāzì's contemporaries, in particular those in the theological (kalām) school known as the Mu'tazila (section 1). Then, drawing on a previous discussion by Thérèse-Anne Druart, I will present alRāzì's views on the psychology of animals: which faculties they can possess, and how close they come to resembling humans (section 2). This will take us into a brief digression, in which I argue that al-Rāzi did not endorse the possibility of animal transmigration, as has been more or less universally supposed (section 3). Finally, I will show how his treatment of animal welfare fuses the Platonic idea of 'imitating God' with Mu'tazilite conceptions of God's justice (section 4).

\section{Animals according to the Mu'tazila}

The Mu'tazila styled themselves as the upholders of God's oneness (tawhid) and justice (' $a d l$ ). They were confident (according to their detractors, too confident) in supposing that the implications of God's oneness and perfect justice could be discerned by human reasoning. Their reflections on the oneness of God have led them to a rigorous assertion of divine simplicity: they deny that God has a body and even that He has divine attributes which are in any way distinct from God Himself. In adopting this stance, they were in effect trusting in reason to determine the meaning of revealed truth. For instance rational reflection on God's incorporeality shows that we must

\footnotetext{
5 Both works are edited in al-Rāzì 1939, cited by page and line number, in my own translations. For translations of The Spiritual Medicine see Arberry 1950; Brague 2003. For translations of The Philosophical Life see Arberry 1967; Butterworth 1993; and McGinnis/Reisman 2007. Both works are translated in Tornero 2004 and summarized in Bausani 1981.
} 
take passages in the Qur'ān in a figurative sense when they speak of God's sitting on a throne or having a face. Similarly, they believed that we can to a considerable extent determine what must be involved in God's justice. For instance, their well-known doctrine on free will invokes the rational requirement that God cannot justly punish those who lacked freedom when they sinned.

One of the more surprising features of the Mu'tazilites' theory of justice is the way they talk about God's treatment of animals. As it happens, the longest and most important work on the subject of animals near the time of al-Rāzì was written by an author with $\mathrm{Mu}$ 'tazilite sympathies: al-Jāhiz (d. 869). He managed to be both a theologian of some importance, having associated with the great $\mathrm{Mu}$ 'tazilite al-Nazzām (d. 836), and a leading practicioner of adab ('belles-lettres'). His massive treatise The Book of Animals (Kitāb al-Hayawān) is more representative of his output as an $a d \bar{i} b$ than a $\mathrm{Mu}$ 'tazilite, since it is basically a collection of anecdotes about animals, albeit one that digresses widely. ${ }^{6}$ For our purposes, a more helpful author is the Qādī 'Abd al-Jabbār (d. 1024). His voluminous summa of $\mathrm{Mu}$ 'tazilite doctrine, the Muginni fì abwāb al-tawhīd wa-l-'adl (Comprehensive Work on Topics of Oneness and Justice), touches on the question of whether or not God rewards and punishes animals. ${ }^{7}$ Here I have the luxury of referring the reader to Heemskerk's discussion of this topic in the Mugini ${ }^{8}$

As Heemskerk shows, 'Abd al-Jabbār believes that children, the insane, and animals fall short of the requirements for moral obligation (taklif). Yet such agents do feel and cause pain, which has implications for God's just action towards them. When animals feel pain in their earthly lives God's justice requires Him to compensate them in the hereafter, for instance with food and drink. When they cause pain, the animals must compensate for the harm they have done, for instance when snakes help God by tormenting sinners in hell. ${ }^{9}$ This may seem to be in some tension with the aforementioned $\mathrm{Mu}$ 'tazilite belief that God can dispense justice only to agents who possess freedom. But 'Abd al-Jabbār points out that animals are capable of acting or refraining from action, which suffices. ${ }^{10}$ God must obviously intervene in order to ensure that each animal receives and gives precisely the reward or punishment that is owed to them as a result of the pain they have caused or felt in this life. Heemskerk thus compares God to "a sort of bookkeeper". ${ }^{11}$

6 Al-Jāhịiz 1968.

7 For a general study see Hourani 1971.

${ }^{8}$ Heemskerk 2000, $163 \mathrm{ff}$.

9 Heemskerk 2000, 187-189.

10 Heemskerk 2000, 165; see 'Abd al-Jabbār 1962, vol. 13, 476.12-20.

11 Heemskerk 2000, 178. 
I would like to emphasize three features of this account: first and most obviously, 'Abd al-Jabbār's idea that divine justice is owed to animals as well as to humans. Second, as already emphasized above, the claim that it is possible for humans to discern the requirements of divine justice. Third, the application of divine justice is worked out largely with reference to the causing and compensation of pain. As we shall see later, al-Rāzī's discussions of the ethical treatment of animals share all three of these features. Therefore, I will be suggesting that al-Rāzì may have been reacting to $\mathrm{Mu}$ 'tazilite ideas on the subject of animals. Historically speaking, this is quite plausible. We know that al-Rāzi engaged in detailed debates with $\mathrm{Mu}$ 'tazilites of his own time, especially Abū l-Qāsim al-Balhīi (known as al-Ka'bī); furthermore, Marwan Rashed has uncovered evidence of further discussions between al-Rāzi and Mu'tazilite theologians. ${ }^{12}$ Indeed, it is my view that much of al-Rāzì's philosophical output can be understood as a reaction to $\mathrm{Mu}$ 'tazilism. Obviously it would exceed the purposes of this article to argue for that claim here. Rather, the case of animals and their suffering is offered as a small piece of evidence in this direction.

Before we explore the resonances between Mu'tazilism and al-Rāzìs stance on the treatment of animals, in the next section, I will need to say something about his philosophical understanding of animals more generally. But before doing that, I should deal with a possible objection: the theologian I have just used as representing the $\mathrm{Mu}$ 'tazilite view on animals and divine justice is 'Abd al-Jabbār, who died more than a century after alRāzì did. Can we really use him for evidence of Mu'tazilite ideas in al-Rāzì's day? Certainly, 'Abd al-Jabbār's Muginī is a long, complex work which offers intricate, one might say scholastic, detail on a vast range of topics. So it must inevitably be more than just a summary of Mu'tazilism as it already existed a century before. One might additionally worry that 'Abd al-Jabbār was carrying on the ideas of the Basra school of $\mathrm{Mu}$ 'tazilites, whereas alRāzì seems to have engaged more with the Baghdad school (notably their foremost representative, the aforementioned al-Ka' $\mathrm{bi}^{\mathrm{i}}$ ).

Nonetheless, there is good evidence that 'Abd al-Jabbār was extending ideas about animals current in $\mathrm{Mu}$ 'tazilism before al-Rāzì's time. Because there are hadi $\underline{t}$ which forbid the mistreatment of animals, ${ }^{13}$ even early theologians were naturally led to wonder about the basis of such restrictions. The great Mu'tazilite thinkers Abū l-Hudayl and al-Nazzāām both endorsed the theory of așlah: that God does "what is best" for all creatures. This applies to animals as well as to humans because animals too fall under the scope of divine justice. In the aforementioned Book of Animals of al-Jāhiz, we are told the following about al-Naz̧ām:

12 For his relations with the theologians see Rashed 2000.

13 As discussed in Foltz 2006, $19 \mathrm{ff}$.; Benkheira 2005, 136. 
He claimed that the species of animals that have sensation and feel pain are given grace in equal compensation, and that the children of both infidels and Muslims are all in paradise. He claimed that there is no difference between children, beasts and madmen, and no difference between predatory animals and domesticated beasts. He said that these animal and beast bodies do not enter paradise, but rather God, the exalted, sets their spirits ( $a r w \bar{a} h)$ free from those harms, and puts them together in whatever [bodily] forms He prefers (fi ayy al-șuwar ahabba) (al-Jāhị 1968, vol. 3, 394.9-395.3).14

Thus, the roots of 'Abd al-Jabbār's ideas about animal recompense are already present in $\mathrm{Mu}$ 'tazilism of the 9th century, indeed a couple of generations before al-Rāzì. Moreover, as we will see below in section 3, there is evidence that al-Rāzī was aware of these kalām discussions.

\section{Al-Rāzì on Animal Psychology}

Let us now turn our attention to al-Rāzī himself. To my knowledge the only significant previous discussion of his ideas about animals appears in a groundbreaking article by Thérèse-Anne Druart. ${ }^{15}$ On her interpretation, al-Rāzì believed that animals have rational souls and even partake of 'intellect', although they are not capable of as wide a range of rational activities as humans. If true, this would obviously be remarkable in itself, and Druart adds that it could be relevant to two other aspects of his philosophy. First, al-Rāzì is notorious for having endorsed the transmigration of animal souls into human bodies, and vice-versa. If he believed that animals have rational souls, this would be easier to understand. ${ }^{16}$ Second, Druart suggests that the rationality of animals could be one basis for al-Rāzì's insistence that we treat them well. ${ }^{17}$ I find much to agree with in Druart's analysis, but as will become clear later on, I also disagree with her on several key points.

One of the virtues of Druart's discussion is that it begins in the right place, namely al-Rāzī's medical writings. When reading him, one should never forget that he was first and foremost a doctor, and that many of his philosophical opinions were related to his medical expertise. The psychology of animals is a case in point. In general, it seems that influence from the medical tradition and Galen in particular led philosophers to see a greater degree of continuity between animals and humans. Just think, for instance, of Galen's famous anatomical demonstrations regarding the nervous system. One point of these was that if the brain of vivisected animals such as pigs controls

14 Cited in van Ess 1991-1995, vol. VI, 155. For discussion see vol. III, 407 f.

15 Druart 1996.

16 Druart 1996, 252f.

17 She speaks of the "enormous ethical implications" (op. cit., 252) of such a view, and says that the "continuum" of rational capacities among animals and humans is "the basis for the animals' entitlement to proper treatment as well as punishment" (253). 
their motion and sensation, then the same must be true of humans. ${ }^{18} \mathrm{Al}-\mathrm{R} a \bar{z} \overline{1}$ himself speaks of investigating the effects of ingesting mercury by testing it on an ape. ${ }^{19}$ (He says the result is painful, but not very damaging!) One might also mention here Avicenna's discussion of the internal senses, which postulates a faculty of 'estimation (wahm)' possessed by both humans and animals. Avicenna gives the famous example of the sheep's perceiving the hostility borne towards it by the wolf. A significant aspect of Avicenna's theory is that it matches the various senses with different ventricles of the brain. ${ }^{20}$ Again, here anatomical discussions were part and parcel of a trend towards seeing animals and humans as sharing certain psychological features.

Druart is right, then, to point to the importance of medical texts such as the Introduction to the Art of Medicine (Kitāb al-Madhal ilā l-șina'at altibb) as a basis for al-Rāzī's classification of psychological faculties. ${ }^{21}$ For our question, particularly relevant is chapter 11 on the various faculties or powers (quwan). Al-Rāzi follows a three-fold division with its ultimate origin in Plato's Timaeus. He locates the 'psychological (nafsāniyya)' power in the brain, the 'animal (hayawanniyya)' power in the heart, and the 'natural (tabi 'iyya)' power in the liver. ${ }^{22}$ This terminology might be taken to suggest that animals lack the first type of power; why else would he call the second power 'animal'? That impression is also given by the previous chapter, a general survey of the organs which says that the brain is "the origin of the nerves and the source for sensation, motion, and the rational psychological activities (al-af'äl al-mantiqiyya al-nafsāniyya), that is, the governing [activities] (al-siyassiyya)". These are enumerated as imagination (wahm, al-quwwa al-hayāliyya), "the power of thought, through which one knows the truth of things (al-quwwa al-fikriyya wa-bi-hä tu'rafu haqiqat al-umūr)", and memory. ${ }^{23}$ Al-Rāzi says nothing here to indicate whether or not animals have these capacities. But strikingly, when he goes on to discuss the role of the heart, which is "the origin and source of life", he mentions that it provides 'animal pneumas (al-riyāh)' and that "there is no animal without a heart or something equivalent; or without blood or something equivalent". ${ }^{24}$ This could, again, be taken to imply that all animals have the vital functions based in the heart, whereas not all animals have the 'psychological' and 'governing' functions based in the brain.

18 Another point of such demonstrations was to demonstrate mastery, indeed superiority over other experts. See von Staden 1995, Gleason 2009.

19 Al-Rāzì 1987, 368, cited in Pormann 2008, 111.

20 See Black 1993.

21 Al-Rāzì 1979, quoted by chapter and section number, with page and line number from the Arabic edition. This is also discussed by Druart 1996, 250-252.

22 Al-Rāzī 1979, § 11 (introduction), 70.1-3.

23 Al-Rāzì 1979, § 10.1, 65.5-8. These are repeated as the three "governing powers" at $\S 11.1,70.4 \mathrm{f}$.

24 Al-Rāzì 1979, § 10.2, 65.11-66.4. 
But clearly, it would be hasty to conclude from this that no animals have such functions. Almost all animals do have brains, and presumably every animal has a soul (nafs). So the term 'psychological powers (quwan nafsāniyya)' could be taken to imply that animals have such capacities in addition to their 'animal powers'. Furthermore, it is plausible that at least some animals have imagination and memory, if not the capacity for thought (fikr). Things are complicated further by the fact that in chapter 11, after mentioning the three types of governing power again (imagination, thought, memory), al-Rāzì postpones any treatment of these until he has discussed voluntary motion and sensation. There is no indication that these two faculties count as "psychological governing powers". They seem to be distinct from imagination, thought and memory in that they involve the entire nervous system and not only the brain. ${ }^{25}$ It goes without saying that many animals possess these two powers. But al-Rāzī says nothing explicit about animals until after he has discussed the powers seated in the heart and liver. Only then does he make the general observations that all animals (as well as plants) require some degree of moisture in their composition, and that animals become drier as they mature. Furthermore all animals have innate heat. ${ }^{26}$

The upshot is that this rather schematic treatment of the powers of living things and their associated organs has not taken us very far. Here I must disagree with Druart, who says that because motion and sensation are functions exercised through the nerves by the brain, they "are presumably subject to" imagination, thought and memory. She then infers that since animals can move and sense, they must be rational. ${ }^{27}$ But neither of these inferences seems warranted. There is no sign that either motion or sensation require all three 'governing' powers. Indeed it is not stated that animals have any of the three governing powers, however plausible it might be to say that they must have at least imagination in order to move. Al-Rāzì does refer to the governing powers as 'rational (mantiqi) ', as mentioned above. But again it is not obvious that a creature which possessed, for instance, only memory and imagination but not thought (fikr) would count as 'rational (nāțiq)'. ${ }^{28}$ Besides, as noted above, there are signs that al-Rāzī sees

25 This is stated nearly explicitly at one point: "the activities of the brain are twofold: those performed by the brain on its own and those performed through an organ. It is the governing power that is performed by the brain on its own, and sensation and motion that are performed through an organ", namely the nerves (al-Rāzī 1979, § 11.4, 72.2f.).

26 Al-Rāzì 1979, § 11.8 .

27 Druart 1996, $251 \mathrm{f}$.

${ }^{28}$ Here it is important to remember that in this text al-Rāzi is talking about medicine for treating humans, so his discussion of the powers and their anatomy may well be restricted to the human case. For instance, he situates the various governing faculties in the parts of the brain, he surely has in mind the human brain (which leaves open 
the merely vital functions as distinctive of animals. He calls these the 'animal' powers and insists that all animals have a heart and blood, or their equivalent. Nothing similar is claimed regarding the brain and nerves.

Druart might rightly reply here that by the same token, nothing in the medical Introduction would rule out the ascription of rationality to animals. After all, they do have brains, and are capable of self-motion and sensation, so they might have all the governing powers. Here it would seem particularly pressing to decide whether, according to al-Rāzì, at least some animals possess the capacity to think. If so, does that mean that animals are 'rational'? Would al-Rāzì go so far as to ascribe 'aql ('mind' or 'intellect') to them? As for the other functions realized through the nervous system, one might concede that animals are capable of self-motion, but wonder whether they are able to choose between alternative motions. The expression 'voluntary motion (haraka bi-iräda)' is used in the medical Introduction, ${ }^{29}$ but even if we take for granted that this expression applies to animal motions (which again is not stated explicitly) that would not settle the question as to whether some animals are capable of full-blown choice (ihtiyār).

Thus establishing more clearly what al-Rāzī thinks about animal psychology requires answering several related, but distinct questions. For each distinct human function, we need to ask whether or not it is exercised by at least some animals. It is uncontroversial that many if not all animals possess at least some capacity for sensation and of course the functions associated with life. But we might well wonder:

(1) Are animals capable of imagination, thought and memory?

(2) Are they 'rational (nātiqu)'?

(3) Do they have 'intellect ('aql)'?

(4) Are they capable of 'choice (ihtiyār)'?

I take it that, if on al-Rāzì's view the answer to any of these questions is 'no', then it will turn out that for him animals do have souls of a fundamentally different sort than those possessed by humans. Moreover, as I will now show by turning to al-Rāzì's other works, the answers to our four questions are as follows: (1) yes, (2) no, (3) no, and (4) perhaps. This rather undercuts Druart's suggestion that al-Rāzì's animal psychology would fit neatly with his doctrine of transmigration and constitute the foundation for his ethical stance on animals. That may strike some readers as unfortunate. Druart's interpretation is not only ingenious, but deftly ties together several apparently unrelated aspects of Razian philosophy. But I will argue that this vir-

whether animal brains are similar, and if so how). In such a context it would be reasonable for him to follow Plato and Galen by speaking of 'rational' powers in the human case without meaning to imply anything about the rationality of non-human animals.

29 Al-Rāzì 1979, § 11.2, 70.6f. 
tue of her reading is largely illusory. For one thing, as I argue in section 3, there is no need to relate Razian psychology to transmigration, because alRāzì did not in fact believe in animal reincarnation. As for his ethical stance on animals, I will show in section 4 that it relies exclusively on the fact that animals feel pain, and not on any other feature of animals shared in common with humanity.

Let us then turn to our four questions. As Druart has pointed out, ${ }^{30}$ there are passages in al-Rāzì's Spiritual Medicine which seem to ascribe (1) the 'governing powers' to animals. The idea that animals are capable of thought (fikr) can perhaps be coaxed out of a passage mentioned by Druart. ${ }^{31}$ In this passage al-Rāzì says that anyone who fails to seek knowledge has "a share in reason $(n u t q)$ like that of the beasts $(b a h \bar{a}$ im), or in fact (la bal) of bats, fish, and other worthless creatures which neither think (tatafakkaru) nor consider (tatadakkaru) at all". ${ }^{32}$ On the face of it this looks like al-Rāzi is saying that people become like animals when they do not think, which certainly suggests that animals do not engage in thought. But it could also be taken to mean that thoughtless people are specifically like bats and other debased creatures which are mindless even by the standards of the animal kingdom. This would imply that some other kinds of animal do, by contrast, engage in thinking and considering, albeit perhaps to a lesser extent than humans. Against this reading there are other passages in this very chapter of The Spiritual Medicine where al-Rāzī contents himself with comparing inadequate humans to animals or beasts $\left(b a h \vec{a}^{\prime} \mathrm{im}\right)$ generally (e.g. 23.9f., 24.8, 26.15), without distinguishing between more and less sophisticated animals. 33

In what looks to be a more significant passage regarding question (1), al-Rāzì points out that animals can obtain things and store them away. He then remarks: "it is better [to say] that these animals have more in the way of cognitive representation than those which do not acquire anything". ${ }^{34}$ Though this remark is introduced seems rather tentative, one cannot but be struck by the idea that some animals have tașawwur fikrī, which

30 Druart 1996, 252f.

31 Druart 1996, 252.

32 Al-Rāzī 1939 29.15-17. Druart 1996 apparently reads hayyāt, "vipers", for hìtān, "fish". The two terms are very similar in a palaeographical sense.

33 Druart considers this passage to be weak evidence in favor of her own view; but I think for the wrong reason. The problem is not that the passage is "a piece of rhetorical exaggeration", as she puts it - though it may be that as well. The difficulty is rather that it is not clear from the passage whether al-Rāzi in fact envisions two classes of animals at all. The point may be simply that if one refuses to think, one is like an animal. The force of $l \bar{a}$ bal would then be to show the reader what sort of lowly creatures are included among animals, all of whom are deemed thoughtless.

34 Al-Rāzì 1939, 83.5f. 
I've translated as 'cognitive representation'. ${ }^{35}$ We seem to have here at least 'thought (fikr)'. We might also take 'representation (tașawwur)' to mean something like imagination, given that al-Rāzì goes on to speak of the animal having a tasawwur of the future situation where the acquired thing will be needed. He seems to have in mind cases such as squirrels putting away nuts for the winter. To make sense of this behavior, it is 'better' to suppose that the squirrels are thinking about, and forming an image (șura) of, the wintry situation in which they will eat their cache of nuts. In any event, this passage seems to indicate that al-Rāzi at least thought that animals may share the 'governing' powers of imagination and thought with humans. ${ }^{36}$

On the other hand, elsewhere in The Spiritual Medicine, he actually says that animals do not plan ahead or envision future events:

Being led by the call to [pleasure] and going along with it is nothing but domination by desire and its obliteration of intellect ('aql). It behooves the intelligent man ( $\left.a l-{ }^{\prime} \bar{a} q i l\right)$ to scorn desire and consider it as beneath him, rather than acting like male goats or bulls, or other beasts (wa-s $\vec{a}$ ir al-bah $\vec{a}$ im) which engage in no reflection (rawiyya) or consideration (nazar) about consequences (al-Rāzì 1939, 76.14-17).

Much as with the passage about bats and fish (al-Rāzì 1939, 29.15-17), this text is susceptible of two alternative interpretations. Perhaps al-Rāzì is saying that all animals fail to consider future consequences, and the goat and bull are mentioned only as striking examples. Or perhaps he means that, whereas goats and bulls are notoriously susceptible to immediate pleasures and pursue them heedlessly, other animals are more circumspect. The end of this chapter suggests that the former reading is correct. There he says that, whereas humans can restrain their pursuit of pleasure by using intellect ' $a q l$ ), "the beast is simply led due to nature, without any check on, or supervision over, what may befall it as a result". ${ }^{37}$ Furthermore, a few pages later, al-Rāzì says that because humans have the capacity for "picturing and inferring intellectually (al-tamtīl wa-l-qiyās al-'aqlī), it frequently happens

35 Druart 1996, 253, translates "an ability to picture to themselves cogitatively", Arberry 1950, "mental imagination".

36 Since I will deny below that animals, on al-Rāzī's account, possess mind or intellect ('aql), I should say something about Druart's remark that the sort of planning envisioned here "is also characteristic of the intellect" (Druart 1996, 253). This is evidently based on the immediately preceding remark of al-Rāzi that "acquisition and putting up supplies too is one of the necessary requirements $(a s b \bar{a} b)$ for the good life, which comes about thanks to the provision of intellectual understanding ('an taqdima al-ma'rifa al-'aqliyya)" (al-Rāzì 1939, 83.2-4). But this remark clearly refers to humans, since the case of animals is offered as an a fortiori illustration: even "irrational animals" (more on this characterization below) acquire and store things, and humans must do so as well. Animals share with us the behavior of acquisition, but it does not follow that they share "intellectual understanding", any more than it follows that they can achieve "the good life (husn al-'aysh)".

37 Al-Rāzī 1939, 77.9-12. 
that we represent to ourselves (natașawara) the consequences of things". He contrasts this to the case of "beasts who rush after that whose conclusions and consequences they do not represent to themselves". 38

This shows, I think, that al-Rāzì did not see planning and representation of the future as a distinctively animal activity, but rather a distinctively human one. The same is true of thought or ratiocination $(f i k r)$. We saw that in the context of explaining how animals store away food, al-Rāzi ascribes to them tasawwur fikrī, 'cognitive representation'. Here it is interesting to compare a passage from earlier in The Spiritual Medicine, about philosophical views which criticize hedonism:

These philosophers put forward the very constitution (hay'a) of man to prove that he is not constituted for occupying himself with pleasures and lusts, seeing how deficient he is in this respect compared with the irrational animals (al-hayawān gayr al-nātiq), but rather for the use of thought and reflection (al-fikr wa-l-rawiyya). For a single beast experiences more pleasure in eating and having intercourse than a large number of men can possibly achieve; while, as for its capacity for lapsing in concern or thought (suqūt al-hamm wa-l-fikr) and enjoying life simply and wholly, that is a state which no man can obtain or replicate [...]. The very fact that man is so deficient in his share of these things [...] whereas he possesses such a share (hazz) of reflection and thought, should teach us that it is better to use reason (nuṭq) (al-Rāzī 1939, 24.11-25.5; trans. Arberry, modified).

This passage has much in common with several we have examined above. On a first reading, it looks like al-Rāzì's point is that humans, unlike animals, are capable of thought and reflection. The ethical implication is that a good human deploys these capacities to rise above hedonism. But on closer inspection, it looks like he may be conceding that animals have a minimal capacity for fikr. Particularly striking is the idea that animals readily lapse from thought, which hardly makes sense if they never engaged in thought at all. The statement that humans have a large share of rawiyya and fikr could also be taken to imply that animals do have a small share.

The Spiritual Medicine, then, presents us with a rather ambivalent stance on animals' capacity for fikr: it seems to be ascribed to animals several times, yet almost always in order to emphasize the extent to which animals lack this capacity, at least in comparison to humans. One might insist that this is simply a consequence of al-Rāzī's ethical subject-matter, and hold on to the interesting fact that he does seem to be ascribing a minimal degree of fikr to animals. Indeed, this is all that Druart infers from the passages she cites from The Spiritual Medicine. Yet by the same token, the evidence examined above hardly indicates that al-Rāzì wants to emphasize animals' possession of the governing faculties, or sees it as important that animals share faculties with humankind. After all, he hints that they have such fac-

38 Al-Rāzì 1939, 85.16 and 86.5. 
ulties precisely when pointing out the poverty of animal psychology relative to humans.

Furthermore, al-Rāzì explicitly states in two passages of The Spiritual Medicine that animals lack the capacity for deliberation or consideration, rawiyya:

For the chief way people are better than beasts is this: the faculty of volition (malakat $a l$-irāda) and the dispatch of action after deliberation (ițlāq al-fi'l ba'd al-rawiyya). For

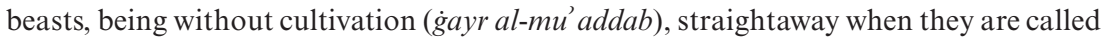
to something by nature, do that thing without hesitating or deliberating about it (al-Rāzì 1939, 20.10-12).

One should control oneself so that, when one is angry, one acts only after thought and deliberation (al-fikr wa-l-rawiyya) [...] one should not be like beasts in unleashing action without deliberation (wa-lā yušăriku al-bahä im fì iṭlāq al-fi'l min ġayr rawiyya) (al-Rāzī 1939, 56.2-4).

Al-Rāzì frequently associates fikr with rawiyya - they appear commonly as a couplet, as in the second passage just cited. ${ }^{39} \mathrm{He}$ also strongly associates 'aql with fikr in the medical introduction, when he says that "the destruction of thought occurs when the man entirely lacks intellect". ${ }^{40}$ As we will see shortly animals most definitely lack 'aql, according to al-Rāzì. All this indicates a significant deficiency on the part of animals concerning thought: if they have this faculty at all, it is not linked to deliberation and intellect, as it is in humans.

A very different impression, however, is given by a fascinating passage in another work by al-Rāzī, his Doubts About Galen. ${ }^{41}$ It appears in the section of the work criticizing Galen's On the Doctrines of Plato and Hippocrates. $\mathrm{He}$ is considering a Galenic diatribe against Chrysippus and the Stoic view that the ruling faculty is located in the heart, as opposed to the brain. Al-Rāzi cites two passages from Galen. ${ }^{42}$ The first says that emotions, but not thought (fikra), are seated in the heart - something al-Rāzi finds doubtful because emotions such as grief actually require thought (al-Rāzi 1993, 26.20). The second quotation says that "infants and beasts are angry, afraid, happy, and sad, without using thought", but again al-Rāzì is not persuaded:

39 This is a common pairing in philosophical literature up to his time. For instance in the Arabic Plotinus, the couplet is used to express the concept of dianoia or discursive reasoning. See Adamson 2002, 98.

40 Al-Rāzì 1979, § 13.4, 81.2.

41 Al-Rāzi 1993, 26.15-27.6. I am grateful to Fritz Zimmermann for bringing this text to my attention, and to Pauline Koetschet for discussion of the passage.

42 These are identified by Strohmaier 1998, 277, as CMG V 4,1,2, 210.38-212.4 ("etwas frei") and $C M G$ V 4,1,2, 214.10-13 ("frei und verkürzt"). As Strohmaier notes, 'ași needs to be emended to gadabī at al-Rāzī 1993, 26.17. 
The opponent will say that these [sc. infants and beasts] use thought to the extent ${ }^{43}$ required to perform such actions. For, if they could not conceive that the individual confronting them was harmful, they would not shun and fear it, for instance a lion or the like. And [if they could not conceive] that something else would be good ${ }^{44}$ for them, they would not be cheerful and calm towards it, for instance what the dog does with its master, and riding animals (dawābb) with their driver. How can anyone say that beasts have no thought at all (la fikr li-l-baha $\bar{a}^{\prime}$ m așlan), given the amazing things they are seen to do? Have you considered that a mouse, by inserting its tail into a narrow-mouthed bottle, dipping it into the oil, and licking it, is able to get at [the oil] it wants, because it realizes that its head is too big to fit through the mouth of the bottle, and that it could not do this without conception and reflection (al-tașawwur wa-l-rawiyya)? So it ought not be said that what is in them is only very slight in comparison to what is in man ( mā fì-hā qalìl jiddan bi-l-iḍa fa ilā mā fì l-insān) (al-Rāzì 1993, 26.22-27.6).

This remarkable text anticipates Avicenna's point that animals require a relatively sophisticated cognitive function (Avicenna calls it wahm, al-Rāzì calls it tașawwur) to grasp such things as the hostility of a predator (here a lion, instead of Avicenna's famous example of the wolf). The delightful example of the mouse is then used to support an unambiguous assertion of fikr and rawiyya in animals.

Admittedly, this is a highly dialectical context, where al-Rāzi is chastizing Galen for giving a less than compelling argument, ${ }^{45}$ and raising a possible argument on behalf of the Stoics. Still, it is hard to read the passage without concluding that the answer to our question (1) is 'yes': al-Rāzì does think that animals are capable of thought $(f i k r)$, as well as memory and imagination. He seems to be of two minds as to whether or not they possess the capacity for rawiyya. In Doubts he is willing to assert this, perhaps because he here treats rawiyya as a synonym for 'thought.' By contrast, The Spiritual Medicine speaks of rawiyya in the narrower sense of considering whether or not to refrain from a certain course of action. In this narrower sense, animals lack the capacity for rawiyya that we observe in humans.

We can deal with questions (2), (3) and (4) more rapidly, beginning with (2): are animals 'rational'? Here the answer is clearly 'no'. Al-Rāzī never applies this word to non-human animals, but on the contrary constantly describes them as 'irrational animals' (this seems to be synonymous with the epithet 'beasts', $a l-b a h \bar{a}^{\prime} \mathrm{im}$ ). He even does so in some of the passages cited above which may allow animals some share in the governing faculties (for instance al-Rāzī 1939, 24.11-25.5: al-hayawān ġayr al-nātị). One telling case is the text which describes animals storing up acquisitions and says they have 'cognitive representation'. Here again al-Rāzì refers to these very

43 Deleting wa-before qadr.

44 Reading hayran.

45 See 26.22: "this claim is not certain, and reaches its conclusion by begging the question", a remark which Mohaghegh wrongly construes as part of the Galenic quotation. 
creatures as 'irrational animals (al-hayawān ġayr al-nātiq)' (al-Rāzī 1939, 83.5). This is no surprise, when we notice the likely source of al-Rāzì's comment. The source is the opening passage of Galen's De Moribus, an ethical work preserved only in Arabic. In that work, Galen has asked whether human 'dispositions $(a h l \bar{a} q)$ ' belong to the rational soul or only the irrational parts of the soul. He then gives the following rationale for the latter view:

This [sc. that the ahlāq belong to the irrational soul] is indicated by the dispositions we observe in babies and in animals that lack reason (al-hayawān alladī lā nuṭq la-hu) [...] There are some that collect food and prepare it for themselves, like the bee and the ant, ${ }^{46}$ and others that acquire food day by day, like the pigeon. ${ }^{47}$

Here the whole point is that the behavior of storing things away is something that non-rational animals can do.

The same goes for (3): do animals possess 'aql? Al-Rāzī denies this numerous times, sometimes very emphatically, as in the opening of The Spiritual Medicine where he praises 'aql as a gift from God:

I say that the Creator, great be His name, gave and granted us intellect ('aql) only in order that through it, we might in this world and the next attain and reach that benefit which is the end attained and reached by a substance such as ours. For it is the greatest blessing of God upon us, the most useful and advantageous thing we have. It is through intellect that we are better than the irrational animal (al-hayawān gayr al-nātiq), so that we rule and control them, subjecting them to us and directing them in ways conducive to our advantage as well as theirs. Through intellect we grasp all that lifts us and improves us, gives delight to our life and brings us to our end and goal (al-Rāzì 1939, 17.16-18.4).

If any confirmation were needed he says shortly after this that without 'aql we would have the status of beasts (18.9f.); elsewhere, he states that animals defecate and eat without hesitation whenever they need to, whereas humans can refrain because of their intellectual conceptions (li-ma'ān 'aqliyya, 20.14). Towards the end of The Spiritual Medicine he similarly remarks that "it is reason (nutq) that makes us [sc. humans] better than beasts" (90.10f.). The parallel suggests that he sees reason and intellect as closely related. Al-Rāzì's position on questions (2) and (3), then, could hardly be clearer: not only do animals lack rationality and intellect, but their lack of these capacities is the crucial difference between humans and animals.

This is not a matter of mere terminology. If we look more closely at alRāzìs reasons for denying rationality and intellect to animals, we can

46 An anonymous referee helpfully pointed out to me that this could allude to the opening paragraphs of Aristotle's Metaphysics (A.1): "those [animals] which are incapable of hearing sounds are intelligent though they cannot be taught, e.g. the bee" (trans. Ross). But actually I think it is even more likely that it is a reminiscence of Phaedo 82b which mentions both bees and ants as relatively gentle and social animals.

47 Edited in Kraus 1937, 25. For a translation of this work see Mattock 1972. 
understand better what these faculties provide for humans. His fundamental idea is that, at least in the context of practical action, $n u t q$ and ' $a q l$ enable us to resist our desires and natural inclinations as well as to forego pleasures. This already emerges from passages cited above, for instance the one about the goats and bulls (al-Rāzi 1939, 76). The view is well-summarized here:

The man of intellect ought to impede and restrain them [sc. desire and nature], never giving them free rein without having first established and considered what will result, imagining and evaluating this and then following the preponderant course, lest he be pained when he thinks he will be pleased (al-Rāzì 1939, 22.4-6).

It is only to be expected that al-Rāzì would closely associate reason with self-control, because this is the role played in his ethical theory by the rational soul. Following Plato and Galen, he thinks that the virtuous man is precisely the one who uses reason to restrain nature and desire. Animals are incapable of this, which makes them worse than us. ${ }^{48}$ On the other hand animals do not go to extremes by pursuing pleasure to an unnatural degree, and this makes them better than licentious and hedonistic humans. ${ }^{49}$ It may also be relevant to mention that the word for 'rational (nātiq)' in Arabic, as in Greek, implies the ability to talk. Unlike Porphyry, al-Rāzī never seems to contemplate the idea that animals can talk.

Finally, what about our final question (4): do animals have a capacity for 'choice (ihtiyār)'? According to The Spiritual Medicine beasts do not exercise choice over what they do (lā muhtāra 'alayhi, at al-Rāzī 1939, 20.15). But as Druart notes, a passage in the work On Metaphysics, which may be by al-Rāzī, does ascribe a capacity for choice to animals. They do not always simply act by nature, but "have various actions such as flying when they need to but remaining still after exertions when there is no need for flying, and their choice (ihtiyarr) of feeding on some things and not on others" ${ }^{50}$ His point here is that animals are not like, say, fire which automatically gives rise to heat. This shows that the Aristotelian theory being attacked in On Metaphysics is, at a minimum, too simplistic: one cannot explain both animal behavior and the heating power of fire by appealing to 'nature', because nature always produces the same result in the latter case, but not in the former. ${ }^{51}$ These remarks do not fit very well with The Spiritual

48 See for instance al-Rāzī 1939, 73.9 f.: someone who lets their desiderative soul dominate them has departed from reason and "entered into a bestial nature (al-bahi miyya)".

49 See the long discussion of this at al-Rāzì 1939, 24-27, which includes several passages cited above.

50 Al-Rāzì 1939, 122.1-6, translation from Druart 1996, 253. This passage in On Metaphysics also ascribes "discrimination (tamyizz)" to animals.

51 This whole section of On Metaphysics criticizes the Aristotelian theory of nature, particularly the claim of Aristotle's Physics that the existence of nature is sufficiently obvious that one need not argue for it. (In fact Aristotle's point was more subtle: qua natural philosopher, there is no need to argue for nature, since no scientist proves the 
Medicine, given that there al-Rāzì instead emphasizes that animals behave more or less automatically because they just follow nature. Yet I suppose that al-Rāzì would be quite capable, in the dialectical context of On Metaphysics, of using the term ihtiyār simply to differentiate animal behavior from the activity of lifeless things such as fire, so as to embarrass his Aristotelian opponents. One should note, incidentally, that the passage in $\mathrm{On}$ Metaphysics does deny that animals attain the level of intellect (122.6).

\section{Transmigration}

Now this seems to leave us with a dilemma. If animal souls are so different from human souls - basically, theirs have no rational part, whereas ours do then how can souls transmigrate from humans into animals and back again? The possibility of such transmigration or metempsychosis (tanāsuh) is one of al-Rāzì's most famous, not to say notorious, doctrines. Thus, it would seem to speak in favor of Druart's interpretation, and against mine, that her reading would make it easy for al-Rāzì to explain animal-human transmigration whereas mine leaves him with a puzzle he never attempts to solve. My solution to this dilemma is a simple one: I deny that al-Rāzi believed in animal transmigration.

Although several scholars have discussed his views on transmigration, it has barely been noticed that the evidence for these views is extremely weak. ${ }^{52}$ As far as I can see, the only passage in which al-Rāzì might be taken to suggest the possibility of animal transmigration is from The Philosophical Life. The context is his impassioned plea for the ethical treatment of animals, to which we shall return below. In the passage that concerns us here, he is trying to explain why despite these ethical strictures it is permissible to kill some animals, such as snakes and scorpions, and meat-eating animals..$^{53}$

existence of his own subject matter.) The author of On Metaphysics argues that what philosophers have ascribed to nature could be explained with other hypotheses, for instance direct divine action. He also refutes various attempts (by for instance Philoponus and Porphyry) to define nature. On this work see Lucchetta 1987.

52 See Alexandrin 2002 and the useful and wide-ranging Walker 1991, which notes the ambiguous and minimal evidence on this topic provided by the Razian corpus. In fact Walker may be hinting at a skeptical interpretation when he says, "obviously, although al-Rāzī was frequently accused of propounding a theory of metempsychosis, an exact and explicit statement of this in his own words is missing except perhaps by implication" (1991, 226).

53 In Quod animi mores (Kühn IV.815), Galen observes that it is reasonable to kill scorpions, spiders and snakes because of their very nature; he goes on to claim that for wicked people death might be better than life. This could have been an inspiration for al-Rāzì's idea that it would be better for such animals to die, if this is indeed his meaning (see below). My thanks to Christopher Gill for bringing this parallel to my attention. 
One reason is that they would kill other animals - so that it actually promotes animal welfare to kill them. The second is as follows:

Souls are not delivered from the bodies (jutat) of animals except from the body of man alone. If this is the case, then the deliverance of souls such as these from their bodies is similar (šabihan) to the path towards and facilitation of deliverance (al-tariq wa-l-tashil ila l-halāss). Because both rationales apply to the animals who only eat meat, it is necessary to eradicate them where possible, because this minimizes animal pain and provides hope (rajä) that their souls may come into better bodies (juțat așlah) (al-Rāzì 1939, 105.2-6).

This passage was the cue for later, hostile authors such as Ibn Hazm and Nāșir-e Husraw to heap scorn on the doctrine of transmigration, which they of course ascribe to al-Rāzí. ${ }^{54}$

Yet it falls well short of proving that al-Rāzì believed in animal-human transmigration. He first says merely that killing animals is similar to helping them towards liberation. Perhaps one might take this to mean that slaying the animals is a way of liberating them. But it could also mean that since it is an evil to be in the body (as implied by the pejorative word jutat which can also mean 'corpses'), the best thing that can be done for these animals is to kill them, even though it will not liberate them in the sense of securing for them an incorporeal existence such as humans may achieve. Why are humans, and not animals, liberated? The likely answer is not that each soul must work through a cycle of bodies before becoming a human and then achieving liberation - no such theory is even suggested in our passage - but rather that according to al-Rāzi it is only the rational soul which can exist apart from the body, ${ }^{55}$ and, as we have seen, animals do not have rational souls.

Why, then, does he say at the end of the passage that animals will get better bodies? Well first, he does not actually say this. He says that one might 'hope' for this to occur. We are not in the realm of deeply held doctrine here. Second, notice that he need not mean that animals are reincar-

54 See the fragments at al-Rāzi 1939, 174-179. Ibn Hazm cites the lost work called On Divine Science for the view, but his paraphrase of the view is clearly based on this text from The Philosophical Life: "Muhammad b. Zakariyyā' al-Rāzī asserted this [teaching] in his book called Divine Science, and said in one of his books: if not for the fact that there is no way (sabil) for spirits to become freed from bodies with bestial forms (suwar bahimiyya) [so as to go] into bodies with human forms, apart from death and slaughter, then it would not be permissible to slaughter any animals at all" (174.6-9).

55 Al-Rāzì ascribes this view to Plato in The Spiritual Medicine, apparently with approval (28.6f.). In this same summary of Plato's account he also specifies that when "the sensitive soul" is freed from the body it survives as living and rational (nätiqatan), deathless and free from pain (30.12-14). Certainly, the passage we are looking at from The Philosophical Life itself says that only human souls can be liberated or freed from bodies, which fits well with the argument of section 2 above that rationality or intellect is the distinctive feature of human souls on al-Rāzìs theory. 
nated in this world as better animals, let alone humans. He might mean simply that God gives the animals a resurrected body in the afterlife, which is better than the body they have had in their earthly life. This would be very like the view of al-Nažāam as quoted above in section 1: "he taught that these animals and beasts do not go to Paradise with their bodies, but God, the exalted, sets their spirits free from those harms, and puts them together in whatever [bodily] forms He prefers". (Notice that he also uses the word așlah, perhaps alluding to the $\mathrm{Mu}$ 'tazilite doctrine also mentioned above in section 1.) On this reading, al-Rāzì would not be saying anything about transmigration but would instead be alluding to a kaläm doctrine about bodily resurrection, which occurs even in the case of animals. Nor would this commit him to the idea that irrational animal souls can exist without bodies, as human souls can do.

I suspect, then, that this is what al-Rāzì means in the passage from The Philosophical Life. My suspicion is bolstered by some further evidence which appears in a recently edited kaläm work by an author named Ibn al-Malāhimī. This work, with the self-explanatory title The Gift for the Theologians in Refutation of the Philosophers, was written in the 12th century and attacked philosophy from a Mu'tazilite point of view. ${ }^{56}$ The work contains two citations of al-Rāzì, whom Ibn al-Malāhịimī knows at second hand via a critical discussion from another theologian, a mysterious al-Jadìdi (or at least this is the editors' reading of the name). Both citations mention animals. The first concerns itself with al-Rāzì's refutation of the view that the soul is a bodily mixture (mijāz). ${ }^{57}$ Here he invokes poisonous animals to prove that the mixture present in some bodies is actually inimical to life in other animals, so that the mixture cannot be the same as soul.

Passing over this argument let's go on to the second citation, which bears more directly on our concerns. This is drawn from a discussion of resurrection $\left(a l-i^{\prime} \bar{a} d a\right)$ :

Ibn Zakariyyâ' argued against it by raising a familiar doubt: some of the world's animals eat others. For instance a cat eats a mouse, then a dog eats the cat, then a wolf eats the dog. So the parts of the predator are formed from the parts of the prey. Which of them, then, does the Exalted resurrect? If you say 'the prey', this is wrong, because it became a different animal; but according to you the right (al-haqq) to be preserved belongs to the prey. If you say 'the predator', this too is wrong, because the right [to be preserved] would go to what does not deserve it ( $\dot{g}$ ayr mustahiqq) (Ibn al-Malāhimìi $2008,179.17-21) .58$

56 Ibn al-Malāhimìi 2008. I owe my awareness of the passage discussed below to Professor Madelung, who mentioned it in a presentation on this work at SOAS in September 2010.

57 Ibn al-Malāhimī 2008, $159 \mathrm{f}$.

58 The late David C. Reisman was very helpful to me in discussion of the passage. 
As Ibn al-Malāhimī remarks, the argument starts from a familiar objection against bodily resurrection; it is sometimes applied to humans who are eaten by cannibals. The objection is of course that if creature A eats creature B, so that B becomes part of A's body, then God cannot resurrect the bodies of both creatures, since the bodies share some matter. The passage nicely illustrates al-Rāzī's characteristic penchant for dialectical argument flavored with a hint of satire. It also establishes that al-Rāzì was aware of $\mathrm{Mu}$ 'tazilite views about God's resurrection of animals. Particularly striking is his awareness that his opponents believe that God owes something to animals which are wronged. They fall under His justice, and must be treated appropriately. So for instance an animal which is eaten should, according to justice, be restored by God ahead of an animal which eats it. This will be relevant below in section 4, and of course makes it more plausible that he alludes to these same views in The Philosophical Life in explaining how someone might justify killing certain animals.

Admittedly, our two scraps of evidence do not really suffice to establish al-Rāzìs settled view (if any) on the prospects for animals who die. Did he think the cat and mouse argument can be overcome, so that animals may perhaps be resurrected in Paradise? For instance, the cat and mouse argument does not rule out that animals will get a new - and perhaps betterbody in the afterlife, rather than the same body they occupied here. (This would yield a possible agreement between al-Rāzī and al-Nazzāām.) Yet another possibility remains, namely that he did think animals can be reincarnated as other animals. After all, this is not ruled out by the cat and mouse argument. In fact, the evidence of Ibn al-Malāhimī could be turned against my interpretation: though it shows that al-Rāzi knew of the $\mathrm{Mu}^{\text {'- }}$ tazilite position on resurrection, it also shows that he disagreed with it. Why would he appeal even tentatively to the idea of resurrection for animals in The Philosophical Life, if he rejects it emphatically elsewhere? Still, I think the evidence just presented shows that the most plausible reading of The Philosophical Life would take the passage to concern resurrection and not transmigration. Be that as it may, there is certainly no evidence that animals can, on his view, be reincarnated as humans or vice-versa. ${ }^{59}$ This, as I have said above, undercuts the motivation for Druart's reading, since al-Rāzī has no need to explain how the same soul could take on both human and animal bodies.

59 There is, however, evidence that he believed it possible for humans to persist after death as demons (shayātịn). See al-Rāzì 1939, 175. 


\section{The Ethical Treatment of Animals}

Al-Rāzī sets out his rationale for treating animals well in The Philosophical Life as follows:

We say that, in light of the principle we put down - namely that our Lord and Master is concerned for us, watches over us and is merciful (rahim) to us - it follows that $\mathrm{He}$ also hates for us to suffer pain, and that all the pain we do suffer which is not our fault or due to our choices (laysa min iktisābina wa-ihtiyārātināa) but is by nature, is something necessary ( dar $\left._{\bar{u}} \mathrm{r} \bar{l}\right)$ and unavoidable. From this it necessarily follows that we must cause no pain at all to anything capable of sensation, unless it is deserved (min $\dot{g} a y r$ istihq $\bar{a} q$ ), or unless by this pain we can prevent another which is worse (al-Rāzī 1939, 103.14-18).

The allusion to a 'principle' already set down refers back a page or so, to a similar text in which al-Rāzì has stated that we were created not for pleasure, but to acquire knowledge and exercise justice (' $a d l, 101.16$ ). God shows mercy towards us and "loves our justice and knowledge", but "will punish in fair measure those of us who cause harm and those who deserve to suffer pain" (101.18-102.1, trans. McGinnis/Reisman). In this passage, al-Rāzī extends the point to animals as well as humans, hence his statement that we should cause no pain to anything that has sensation.

In accounting for this principle, Druart and others have pointed to a reminiscence of the Platonic ideal of the 'imitation of God (homoiosis theôi)' in Razian ethics. ${ }^{60}$ The ideal derives ultimately from Plato's Theaetetus (176b). It became one of the leitmotifs of ancient ethics and finds its way into Arabic philosophical sources as early as al-Kindī. ${ }^{61}$ So it is no real surprise to see it turn up in al-Rāzi. In fact, he refers to it explicitly later in The Philosophical Life when he writes:

The Creator is knowing without being ignorant and just without being unjust, and is absolute knowledge, justice and compassion (rahma). We have a Creator and Master, and are his servants ('abid) [...] and the servants most beloved of their masters are those who take up their way of life (sira) and follow their course of action (sunan). So the servant closest to God, the exalted, is the one who is most knowing and most just, the most compassionate and benevolent. This whole statement is summarized in the philosophers' remark that 'philosophy is imitation (tašabbuh) of God, the exalted, insofar as lies within the capacity of man'. (al-Rāzī 1939, 108.4-9)

So the Greek antecedents of al-Rāzì's ethical principle are beyond doubt. Yet it's equally clear that he is fusing the Platonic ideal of godlikeness with Islamic themes. Hence the references to God's mercy, His attributes ('knowing', 'just'), His habitual course of action (sunan), and our status as His ser-

60 See Druart 1996, 256, and also Butterworth 2005, 274.

61 See Sedley 1997; for a longer version Sedley 1999. The ideal appears in al-Kindi's definitions of 'philosophy' in On the Definitions and Descriptions of Things, in al-Kindi 1950-1953, vol. 1, 172. 
vants. Here, al-Rāzì is appealing to the religious sensibilities of his readers. It is on this basis that he expects them to endorse the ethical principle quoted above ("we must cause no pain to anything capable of sensation"). This is why he feels free simply to presuppose God's justice, mercy, and mastery over us in support of the principle. The explicitly dialectical nature of the discussion is also shown by his immediately following remark, "let this be agreed by us, so that we can build on it" (102.4f.). ${ }^{62}$

But the context of The Spiritual Life and its ethical teaching regarding animals is not merely Islamic; it is specifically $\mathrm{Mu}$ 'tazilite. One sign of this is that we are allowed, in imitating God, to mete out pain when it is deserved (note that the word istihqa $q$ in the first passage quoted above also appears in his cat and mouse argument, as quoted by Ibn al-Malāhimī). This is symptomatic of two more fundamental points of agreement between alRāzi and the Mu'tazila. First, animals fall under the scope of justice. This is not nearly as obvious as al-Rāzì makes it seem - the bone of contention between Porphyry and his Epicurean and Stoic opponents was precisely the question of whether or not justice applies to animals. But it is an assumption readily available from contemporary $\mathrm{Mu}$ 'tazilite discussions, as we have seen above (section 1). Second, the application of justice is primarily a matter of apportioning pleasure and pain (again see above, section 1). In fact, it consists principally in not causing harm or pain when this is undeserved. This is also confirmed in The Spiritual Medicine:

The way of life which was followed by the excellent philosophers of the past is, in a word, conducting oneself towards others with justice (' $a d l$ ), and in addition to this ( $m i n$ ba'di $\underline{d} \bar{a} l i k a$ ) adhering to generosity ( $f a d l$ ), a feeling of integrity ('iffa), mercy (rahma), guidance (nașh) towards all, and making an effort to benefit everyone, except those who have initiated injustice and wrong (al-Rāzī 1939, 91.7-10).

The idea that one is allowed to inflict harm when it is 'deserved' - and that animals can deserve harm - appeared in a passage we've already considered (The Philosophical Life, 1939, 105.2-6), where al-Rāzī states that one can kill carnivorous animals to stop them from harming other animals. Similar to the predatory creatures in the cat and mouse argument, such animals are legitimate targets of harsh justice. Yet harsh justice is justice all the same. What is required of us - and of God - is that we not inflict harm unless it is unavoidable and serves some useful purpose. Thus al-Rāzì remarks that the overworking of beasts of burden with no good cause are 'wrongs' (mazālim, 104.1), and yet it could be in keeping with 'knowledge and justice ('adl)' to overwork such an animal in extenuating circumstances. He gives the

62 It might be argued that this is in tension with al-Rāzì's notoriously critical attitude towards Islam. But I shall argue in a forthcoming monograph that claims of his hostility towards Islam, or revealed religion in general, are a distortion perpetrated by his Ismā 'î̀i opponents. 
example of straining a horse in order to escape an enemy (104.8f.). The overworking of the horse is especially justified "if that person is learned and virtuous or is rich in some other way that will be of benefit to all people, since $[\ldots]$ his survival in this world is of greater good to the people than preserving the horse" (104.9-11, McGinnis/Reisman translation). ${ }^{63}$ Immediately following this example, al-Rāzì provides a provocative parallel case: if two men are stranded in a desert, with enough water to save only one of them, the water should be given to the man who "is more helpful in doing good (bi-l-saläh) for the people" (104.13).

The example brings a couple of thoughts to mind: first, an expert doctor such as al-Rāzì himself would be an excellent claimant for the water. So the thought experiment may be a subtle part of the self-justificatory project of The Philosophical Life. Second, this is indeed a thought experiment, an illustrative story which would be at home in modern discussions of consequentialist ethics. ${ }^{64}$ Indeed one can hardly help being struck by how consequentialist al-Rāzī seems in this part of The Philosophical Life. No harm or pain should be inflicted on animals, unless the act will secure a greater good. Harm or pain to animals can be balanced against the welfare of human beings - all sentient beings enter into the calculation. Moreover, although one can 'deserve' harm or pain, this is always understood in terms of having inflicted harm or pain on someone or something else. The same criteria are operative in The Spiritual Medicine, though here the question of how to treat animals is not developed as extensively as in The Philosophical Life. For instance al-Rāzī remarks that one irrational behavior indulged in by pleasure-seekers is that they will cause pain to animals to further their own enjoyment (24.9f.). Similarly, those who seek dominion are said to be irrational in pursuing rule "over people and all other animals" (29.9f.). In such cases, we are given to understand, the end does not justify the means, namely the maltreatment of animals.

Notice that this apparently consequentialist treatment of animal ethics presupposes no robust theory about what humans share with animals. The only relevant commonality is that animals, like humans, can feel pain or be harmed (an important distinction, because al-Rāzì also forbids needless killing of animals, which would be harmful to them even if it did not involve pain). Indeed, despite his admirable benevolence towards animals, al-Rāzì

${ }^{63}$ For a reader who knows their Prophetic literature, the example might bring to mind hadì in which Muhammad chastizes others, including his wife 'A' îša, for overburdening pack or riding animals. See Foltz 2006, $19 \mathrm{ff}$. Foltz also mentions that there are hadì $\underline{t}$ which allow for the killing of pests, something else accommodated by al-Rāzì's theory. Cf. Benkheira 2005, 114f., 136.

64 Although a case like this was discussed in Hellenistic philosophy: how would a Stoic sage (or two sages) decide who should get to cling to the only floating plank after a shipwreck? See Cicero, De officiis III.23, also alluded to in the anonymous Commentary on Plato's Theaetetus, quoted at Long and Sedley 1987, § 57H. 
is in no doubt whatsoever that humans are better than animals and that the former deserve greater consideration in our ethical calculation than the latter. This is already shown by the example of the rider who overworks his horse - although it makes a difference who is riding the horse! Al-Rāzì is happy for us to subordinate animals and use them to further our purposes, as long as we don't harm them needlessly. This is shown by the passage cited above in section 2, from The Spiritual Medicine (al-Rāzi 1939, 17f.): "we rule and control [animals], subjecting them to us and directing them in ways conducive to our advantage as well as theirs". Likewise, in The Philosophical Life he allows for the raising of livestock within the bounds of gentle treatment: we should slaughter them only "in accordance with need" (105.7-12).

But is al-Rāzì really a consequentialist, at least when it comes to the treatment of animals? A moment's reflection will show that he is not. While it is true that he lays great emphasis on avoiding unnecessary harm or pain, this is not ultimately because of the intrinsic badness of harm and pain. ${ }^{65}$ Rather, we should avoid causing harm and pain because God wants us to, or because this is a way of behaving that makes us more like God. Thus, the apparent consequentialism of his account must be understood in light of a more fundamental point, which is that God's justice is the foundation of morality. Considerations of harm and pain only enter the picture because of God's preferences: He would not inflict unnecessary harm and pain upon us, and so neither should we inflict this on animals or on each other. This theological ethical stance has important connections to al-Rāzì's cosmology, as set out in his five-eternal theory. As Marwan Rashed argues, that theory is at its heart a theodicy. For instance, al-Rāzi postulates the eternal principle Soul, in addition to God, in part to explain why the world has so much suffering in it despite God's perfect justice. ${ }^{66}$

This brings us back to the point I made above, that al-Rāzi is following the $\mathrm{Mu}$ 'tazilites in believing that justice applies to animals as well as to humans. This is in fact only one manifestation of a kalam theme that runs through his ethical thought: the primacy of God's justice. On the other hand, saying as I have just done that "God's justice is the foundation of morality" might imply that al-Rāzī is departing from the $\mathrm{Mu}$ 'tazilites in another respect. For they famously held that God follows a norm of justice, rather than defining justice with His command. What about al-Rāzì? Does he adopt a divine command theory of justice such as the Aš'arites will do? This is too large a question to pursue here in any detail, but I believe that on

${ }^{65}$ Let alone the intrinsic goodness of pleasure. It has been alleged that al-Rāzì follows the Epicurean tradition in making pleasure the good which guides ethics. But I have shown elsewhere that he is far from thinking any such thing: see Adamson 2008.

${ }^{66}$ See Rashed 2008. Rashed aptly remarks, "en concevant sa doctrine des cinq principes coéternals à Dieu, Rāzī entendait seulement sauver la justice divine” $(2008,170)$. 
this point too his view is close to that of the Mu'tazila. He would agree with them that we are in a position to discern what justice requires, using nothing but our reason. This would make it possible to reconcile the ideal of following intellect ('aql), stressed so emphatically in The Spiritual Medicine, with the ideal of imitating divine justice, as stressed in The Philosophical Life. For example, we know by reason and not by revelation that God would not inflict harm on us needlessly. If humans are capable of discerning such requirements of divine justice simply by using their (God-given) reason, then there is no tension between an ethics of rationality and an ethics of godlikeness. Rather, these two ideals turn out to be identical. ${ }^{67}$

'Abd al-Jabbār 1962. Muġnī (Compendium). Ed. M. al-Saqqā. 14 vols. Cairo.

Adamson, P. 2002. The Arabic Plotinus. London.

-. 2008. "Platonic Pleasures in Epicurus and al-Rāzī". In In the Age of al-Fārāaì: Arabic Philosophy in the Fourth/Tenth Century. Ed. P. Adamson. London, 71-94.

Alexandrin, E. R. 2002. "Rāzī and his Mediaeval Opponents: Discussions Concerning Tanāsukh and the Afterlife". Cahiers de studia iranica 26, 397-409.

al-Jāhì 1968. Kitāb al-Hayawān (Book of Animals). Ed. F. 'Ațawī. 7 vols. Damascus.

al-Kindī 1950-1953. Rasă il al-falsafyya (Philosophical Epistles). Ed. M. Abū Rīda. 2 vols. Cairo.

al-Rāzī 1939. Rasà il falsafiyya (Philosophical Epistles). Ed. P. Kraus. Cairo.

-. 1979. Libro de la introducción dal arte de la medicina o 'Isagoge'. Ed., trans. M. Vasquéz de Benito. Salamanca.

-. 1987. Kitāb al-Manșūrī fì l-țibb (Book for al-Manșūr on Medicine). Ed. Ḥ. Al-Ṣiddīqī al-Bakrī. Kuwait.

-. 1993. Kitāb al-Shukūk 'alā Jālīnūs (Doubts about Galen). Ed. M. Mohaghegh. Tehran.

Arberry, A. J. 1950. The Spiritual Physick of Rhazes. London.

-. 1967. "Apologia pro Vita Sua". In Aspects of Islamic Civilization. Ann Arbor, MI, $120-130$.

Bausani, A. 1981. Un filosofo 'Laico' del Medioeve Musulmano. Abu Bakr Muhammad Ben Zakarriya Razi. Rome.

Benkheira, M. H. 2005. L'animal en islam. Paris, 2005).

Black, D. L. 1993. "Estimation (Wahm) in Avicenna: The Logical and Psychological Dimensions". Dialogue 32, 219-258.

Brague, R. (trans.) 2003. al-Razi: La médecine spirituelle. Paris.

Butterworth, C. E. 1993. "The Book of the Philosophic Life". Interpretation 20, 227-236.

-. 2005. "Ethical and Political Philosophy". In The Cambridge Companion to Arabic Philosophy. Eds. P. Adamson/R. C. Taylor. Cambridge, 266-286.

Druart, T.-A. 1996. "Al-Razi's Conception of the Soul: Psychological Background to his Ethics". Medieval Philosophy and Theology 5, 245-263.

Foltz, R. C. 2006. Animals in Islamic Tradition and Muslim Cultures. Oxford.

Gleason, M. W. 2009. "Shock and Awe: The Performance Element of Galen's Anatomy Demonstrations". In Galen and the World of Knowledge. Eds. C. Gill/T. Whitmarsh/ J. Wilkins. Cambridge, 85-114.

${ }^{67}$ I am grateful to the Leverhulme Trust for their support of this research. I also thank Marwan Rashed, audiences at Exeter and London, and two anonymous referees from this journal, for their helpful input. 
Goodman, L. E./McGregor, R. (trans.) 2010. The Case of the Animals versus Man Before the King of the Jinn. Oxford.

Heemskerk, M. T. 2000. Suffering in the Mu'tazilite Theology. 'Abd al-Jabbār's Teaching on Pain and Divine Justice. Leiden.

Hourani, G. F. 1971. Islamic Rationalism: the Ethics of 'Abd al-Jabbār. Oxford.

Ibn al-Malāhimī 2008. Tuhfat al-mutakallimin fì l-radd 'alā l-falāsifa. Eds. H. Ansari/ W. Madelung. Tehran.

Kraus, P. 1937. "Kitāb al-Akhlāq li-Jālīnūs". Bulletin of the Faculty of the Arts of the Egyptian University V.1, 1-51.

Long, A. A./Sedley, D. N. (eds., trans.). 1987. The Hellenistic Philosophers. Cambridge.

Lucchetta, A. 1987. La natura e la sfera. La scienza antica e le sue metafore nella critica di $R \bar{a} z \bar{\imath}$. Bari.

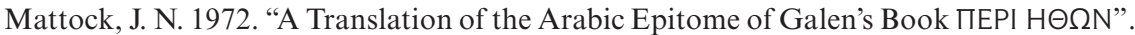
In Islamic Philosophy and the Classical Tradition. Eds. S. M. Stern/A. Hourani/ V. Brown. Oxford, 235-260.

McGinnis, J./Reisman, D. C. (eds., trans.). 2007. Classical Arabic Philosophy: an Anthology of Sources. Indianapolis, IN.

Osborne, C. 2007. Dumb Beasts and Dead Philosophers. Humanity and the Humane in Ancient Philosophy and Literature. Oxford.

Pormann, P. E. 2008. "Medical Methodology and Hospital Practice: the Case of Fourth/ Tenth Century Baghdad". In In the Age of al-Fāräbĩ: Arabic Philosophy in the Fourth/ Tenth Century. Ed. P. Adamson. London, 95-118.

Rashed, M. 2000. "Abū Bakr al-Rāzī et le Kalām". MIDEO 24, 39-54.

-. 2008. "Abū Bakr al-Rāzī et la prophétie". MIDEO 27, 169-182.

Sedley, D. N. 1997. "Becoming Like God' in the Timaeus and Aristotle”. In Interpreting the Timaeus - Critias. Proceedings of the IV Symposium Platonicum. Eds. T. Calvo/ L. Brisson. Sankt Augustin, 327-339.

-. 1999. "The Ideal of Godlikeness". In Plato 2: Ethics, Politics, Religion, and the Soul. Ed. G. Fine. Oxford, 309-328.

Sorabji, R. 1993. Animal Minds and Human Morals. The Origins of the Western Debate. Ithaca, NY.

Strohmaier, G. 1998. "Bekannte und unbekannte Zitate in den Zweifeln an Galen des Rhazes". In Text and Tradition. Eds. K. D. Fischer/D. Nickel/P. Potter. Leiden, 263-289.

Tornero, E. (trans.) 2004. Al-Rāzì: La conducta virtuosa del filósofo. Saragossa.

van Ess, J. 1991-1995. Theologie und Gesellschaft im 2. und 3. Jahrhundert Hidschra. Eine Geschichte des religiösen Denkens im frühen Islam. 6 Vols. Berlin.

von Staden, H. 1995. "Anatomy as Rhetoric: Galen on Dissection and Persuasion". Journal of the History of Medicine and Allied Sciences 50, 47-66.

Walker, P. E. 1991. "The Doctrine of Metempsychosis in Islam". In Islamic Studies Presented to Charles J. Adams. Eds. W. B. Hallaq/D. P. Little. Leiden, 219-238. 